\title{
Knowledge management, customer satisfaction and organizational image discriminating certified from non-certified (ISO 9001) municipalities
}

Elisabeth_Brito__Leonor_Pais__Nuno Rebelo_dos Santos_Cláudia_Figueiredo

International Journal of Quality \& Reliability Management ISSN: 0265-671X

Purpose

The purpose of this paper is to ascertain the extent to which knowledge management (KM), customer satisfaction (CS) and organizational image (OI) discriminate quality-certified municipalities from non-certified ones (ISO 9001).

Design/methodology/approach An empirical study was carried out involving 81 Portuguese municipalities (40 certified, 41 non-certified), paired in a random sampling procedure. The Knowledge Management Questionnaire ( $n=1,372$ municipality employees), the Customer Satisfaction Questionnaire and the Organizational Image Questionnaire ( $n=3,096$ residents) were applied. Multiple discriminant analysis was performed.

Findings

The results indicate that certified and non-certified municipalities are distinct based on a function that considers KM (competitive orientation and formal KM practices), CS (intangible and tangible factors) and OI (favorable image).

Research limitations/implications

The findings need further validation in other countries. However, the results highlight the importance of quality certification for both employees and residents.

Practical implications 
The results encourage local public administration organizations to introduce and maintain quality certification.

Originality/value

This research is the only one, to the authors' knowledge, that simultaneously explores organizational processes of KM, CS and OI in local public administration. The sampling procedure and the information from diverse data sources are unique contributions. The conclusions may aid practitioners and scholars in understanding these organizational phenomena in the context of quality-certified and quality non-certified municipalities.

\section{Citation}

Brito, E., Pais, L., dos Santos, N.R. and Figueiredo, C. (2020), "Knowledge management, customer satisfaction and organizational image discriminating certified from non-certified (ISO 9001) municipalities", International Journal of Quality \& Reliability Management, Vol. 37 No. 3, pp. 451 469. https://doi.org/10.1108/lJQRM-10-2018-0281 